\title{
The health professionals' perception related to the importance of the dental surgeon in the Intensive Care Unit
}

\author{
A percepção de profissionais de saúde relacionada à \\ importância do cirurgião dentista na \\ Unidade de Terapia Intensiva
}

Bruna Lopes SILVEIRA ${ }^{1}$ iD 0000-0002-1111-7461
Dayse Layanne Pereira MENESES ${ }^{1}$ iD 0000-0002-2120-1042
Eduardo Souza de Lobão VERAS ${ }^{1}$ iD 0000-0003-4629-8909
José Pereira de Melo MELO NETO ${ }^{1}$ iD 0000-0002-0699-2675
Luana Kelle Batista MOURA ${ }^{1}$ iD $0000-0003-4917-7598$
Maria Soraya Alves Evangelista MELO ${ }^{1}$ iD $0000-0001-9888-7874$

\section{ABSTRACT}

Objective: To evaluate the perception of ICU professionals about the importance of the dental surgeon in the Intensive Care Unit. Method: Descriptive research, quantitative-qualitative approach. The participants were 22 people, aged 22 years and older who work in the ICUs of private hospitals in the city of Teresina-PI. The data were produced through in-depth interviews in a reserved room of the unit from March 01 to 22, 2018. A semi-structured instrument was divided in two parts: characterization of the participants and open and closed questions on the theme. The data were processed with IRAMUTEC software support and analyzed by means of the Hierar-chical Descending Classification. The research was approved by an Ethics and Re-search Committee with the opinion number 2516806. Results: 22 units of elementary texts were identified, from 68 text segments. A total of 2337 occurrences were rec-orded, using $75 \%$ of the total corpus. The results are presented in two axes: Axis 1 - Diagnosis and installation measures of control of the oral infections in the ICU, di-vided into three classes: class 4, 5, 1. Axis 2 - Conceptual aspects about infections in ICUs linked to the importance of CD, was divided into three classes: Class 2.3, 6. Conclusion: The study concluded that the professionals emphasize the importance of CD in the multidisciplinary team of ICUs to ensure comprehensive and comprehensive treatment of the patient, promoting the possibility of an accurate diagnosis, ad-equate prevention, prognosis and improvement in the quality of life of these individuals.

Index terms: Dentistry. Intensive Care Unit. Oral hygiene.

$\boldsymbol{\nabla} \boldsymbol{\nabla} \boldsymbol{\nabla}$

${ }^{1}$ Centro Universitário UNINOVAFAPI, Programa de Graduação em Odontologia. Rua Vithorino Orthiges Fernandes, 6123, Uruguai, 64073-505, Teresina, PI, Brasil. Correspondence to: L MOURA. E-mail: <luana.moura@uninovafapi.edu.br>.

$\mathbf{v} \mathbf{v} \boldsymbol{v}$

How to cite this article

Siqueira RMP, Marinho ABAS, Santos MTBR, Cabral GMP. The health professionals' perception related to the importance of the dental surgeon in the Intensive Care Unit. RGO, Rev Gaúch Odontol. 2020;68:e20200015. http://dx.doi.org/10.1590/1981-86372 0200001520190055 


\section{RESUMO}

Objetivo: Avaliar a percepção dos profissionais de UTI sobre a importância do cirurgião-dentista em Unidade de Terapia Intensiva. Método: Pesquisa descritiva, abordagem quanti-qualitativa. Participaram 22 pessoas com idade a partir de 22 anos que trabalham nas UTIs de hospitais particulares do município de Teresina-PI. A produção dos dados foi realizada através de entrevistas em profundidade em sala reservada da unidade no período de 01 a 22 de março de 2018. Utilizou-se um instrumento semiestruturado dividido em duas partes: caracterização dos participantes e perguntas abertas e fechadas sobre a temática. Os dados foram processados com suporte do software IRAMUTEC e analisados por meio da Classificação Hierárquica Descendente. A pesquisa teve aprovação de um Comitê de Ética e Pesquisa com o parecer número 2516806. Resultados: Foram identificadas 22 unidades de textos elementares, a partir 68 segmentos de textos. Foram registradas 2337 ocorrências, com aproveitamento de $75 \%$ do corpus total. Os resultados apresentam-se em dois eixos: Eixo 1 - Diagnóstico e instalação medidas de controle das infecções bucais na UTI, divido em três classes: classe 4 , 5, 1. Eixo 2- Aspectos conceitos sobre as infecções em UTI vinculadas a importância do CD, foi divido em três classes: Classe 2,3, 6. Conclusão: O estudo concluiu que os profissionais evidenciam a importância do CD na equipe multidisciplinar das UTIs para assegurar tratamento global e integral do paciente, promovendo a possibilidade de um diagnóstico preciso, adequada prevenção, prognóstico e melhora na qualidade de vida desses individuos.

Termos de indexação: Odontologia. Unidade de Terapia Intensiva. Higiene bucal.

\section{INTRODUCTION}

The intensive care unit (ICU) is a hospital unit characterized by continuously monitoring patients considered to be severely or with decompensated organ systems, providing observational support, constant and intensive treatment by trained teams [1].

Hospitalized ICU patients require rigorous care because they have a clinical picture characterized by immunodeficiency, making them more susceptible to oral and/or systemic infections that aggravate their general health [2].

Dental surgeons (DS) play a fundamental role in oral and oral health assessment, reinforcing the idea that these evaluations influence general health care, since several manifestations in the oral cavity may arise from systemic conditions and that various systemic diseases also may arise from oral conditions [2].

The evaluation of the oral condition and the need for dental treatment in hospitalized patients require follow-up by a qualified dental surgeon in hospital dentistry. Dentistry is necessary to evaluate the presence of oral biofilm, periodontal dis-ease, the presence of caries, oral lesions precursor of viral and fungal infections, traumatic lesions and other oral alterations that represent risk or discomfort to hospitalized patients $[3,4]$. Thus, the patient is more exposed to the risk of infection, and it is noteworthy that patients are five to ten times more likely to increase in their infection [5].

With the need to implant dentistry in the ICUs, the Social Security and Family Commission established mandatory presence of dental professionals in public and private hospitals with ICU patients or wards, approving two bills (PL): No. 2,776/2008 and PL 363/2011, both approved in 2012. This measure aimed to improve the care provided to patients, defend and support the provision of comprehensive health care, which is actually one of the principles of the Unified Health System (SUS) [6].

The participation of dentistry in the interdisciplinary health team is of fundamental importance for the treatment and quality of life of hospitalized patients $[7,8]$.

Guidance on the importance of oral hygiene and quality of health should be extended to all different segments of the multidisciplinary team, but knowledge of the role of dentistry in hospitals is still restricted. It is of utmost importance that there is an interaction between dentistry, other team-forming professionals and patients hospitalized in ICUs during care, in order to minimize the risk of spreading oral cavity pathogens that may cause systemic problems, in this sense, Dental surgeons should work to maintain the hygiene of teeth, gums, cheeks and tongue, controlling the intense colonization of pathogens [9].

However, the literature demonstrates that this team is incomplete in the unit and that the presence of the dentist is relevant for the promotion of the health of the patients to be complete. Given the above, this study evaluated the perception of ICU professionals about the importance of the dentist in intensive care unit.

\section{METHODS}

This study is a descriptive research of quatiqualitative approach seeking complementarity and integration, 
characterizing a type of research called mixed methods research. The information collection consisted of a semistructured questionnaire with open and closed questions, applied in individual interviews with ICU professionals. The research was carried out in the ICUs of four private hospitals in the city of Teresina - PI and was attended by 22 health professionals working within these units, of both genders, and of varying ages who agreed to participate in the research by reading and signing the Informed Consent Form (ICF), through in-depth interviews in a private room of health units from March 01 to 22, 2018. Physicians, nurses, nursing technicians, physiotherapists, psychologists and speech therapists were interviewed. The interviews were recorded on a mobile phone and ended when responses were saturated, and to maintain the anonymity of the original names of the survey participants, they were replaced by "deponents".

The data were analyzed using the IRaMuTeQ software, which performs text data mining, allowing to obtain various quantitative analyzes of the linguistic cor-pus: classic textual statistics (word count), group specificity search, descending hi-erarchical classification, analysis of similarities and word cloud 10 and the following steps were adopted: interview transcription, textual corpus construction consisting of twenty-two (22) interviews and formatted according to the guidelines available in the IRaMuTeQ tutorial. The following fixed variables were chosen as shown.

For analysis, the Descending Hierarchical Classification (DHC) method was defined, in which texts are classified according to their respective vocabularies and their set is divided by the frequency of the reduced forms. From matrices, text and word segments were crossed, the DHC method was applied to obtain a stable and definitive classification [10].

Therefore, the thematic analysis technique was used for the treatment of the material, which, as its name indicates the central concept is the theme, which adheres to a bundle of relationships and can be graphically presented through a word, phrase or a Abstract. The trajectory of content analysis is divided into three stages: pre-analysis, material exploration and treatment of results. Thus, the first stage corresponds to an organization of the material to be analyzed through a strenuous reading of this material, in the second stage there will be an organization of the raw data aggregating them in units of record, that is, it is a search for the nuclei of meaning. And finally, in the third stage, the data are categorized by assigning a degree of significance to the analyzed contents [11].

The research was approved by the Ethics and Research Committee of the Faculty of Health, Humanities and Technological Sciences of Piaui - UNINOVAFA-PI with opinion number $2,628,921$. During the production of the data, the objectives, as well as risks and benefits were clarified to the participants in order to obtain autonomous research collaboration. All participants read and signed the Informed Consent Form.

Upon completion of the study, a copy of the final report will be forwarded to the hospitals where the research took place.

\section{RESULTS}

Twenty-two respondents from four teams working in Intensive Care Units of four private hospitals in the city of Teresina (PI) participated in the research. Out of the respondents, 17 (77.3\%) were female and 05 (22.7\%) were male, with prevalence ranging from 22 to 45 years. Regarding marital status, 12 (54.55\%) were single, 09 (41\%) were married and 01 (4.5\%) divorced. Regarding education level, it was found that 10 (31.2\%) reported having completed higher education (doctor, nurse, physiotherapist, psychologist and speech therapist) and 13 (68.9\%) nursing technicians.

In parallel, about the performance of a DS in the ICU teams and whether such teams adopt any oral decontamination protocol of patients, it was found that $100 \%$ of respondents said that their teams did not have this professional working and $13.6 \%$ of respondents reported that their team does not adopt a specific oral de-contamination protocol and according to $86.4 \%$ of respondents there is an oral hygiene protocol developed by the team itself.

According to the Descending Hierarchical Classification analysis, IRaMuTeQ recognized the corpus separation into 22 units of elementary texts, from 68 text segments. There were 2337 occurrences, with $75 \%$ of the total corpus being used. The classified segments were divided into 6 classes, according to the dendogram shown in Figure 1, with the highest percentage of occurrence and $x^{2}$ value of the classes.

The results are presented in two axes: Axis 1 - Diagnosis and installation of ICU oral infection control 


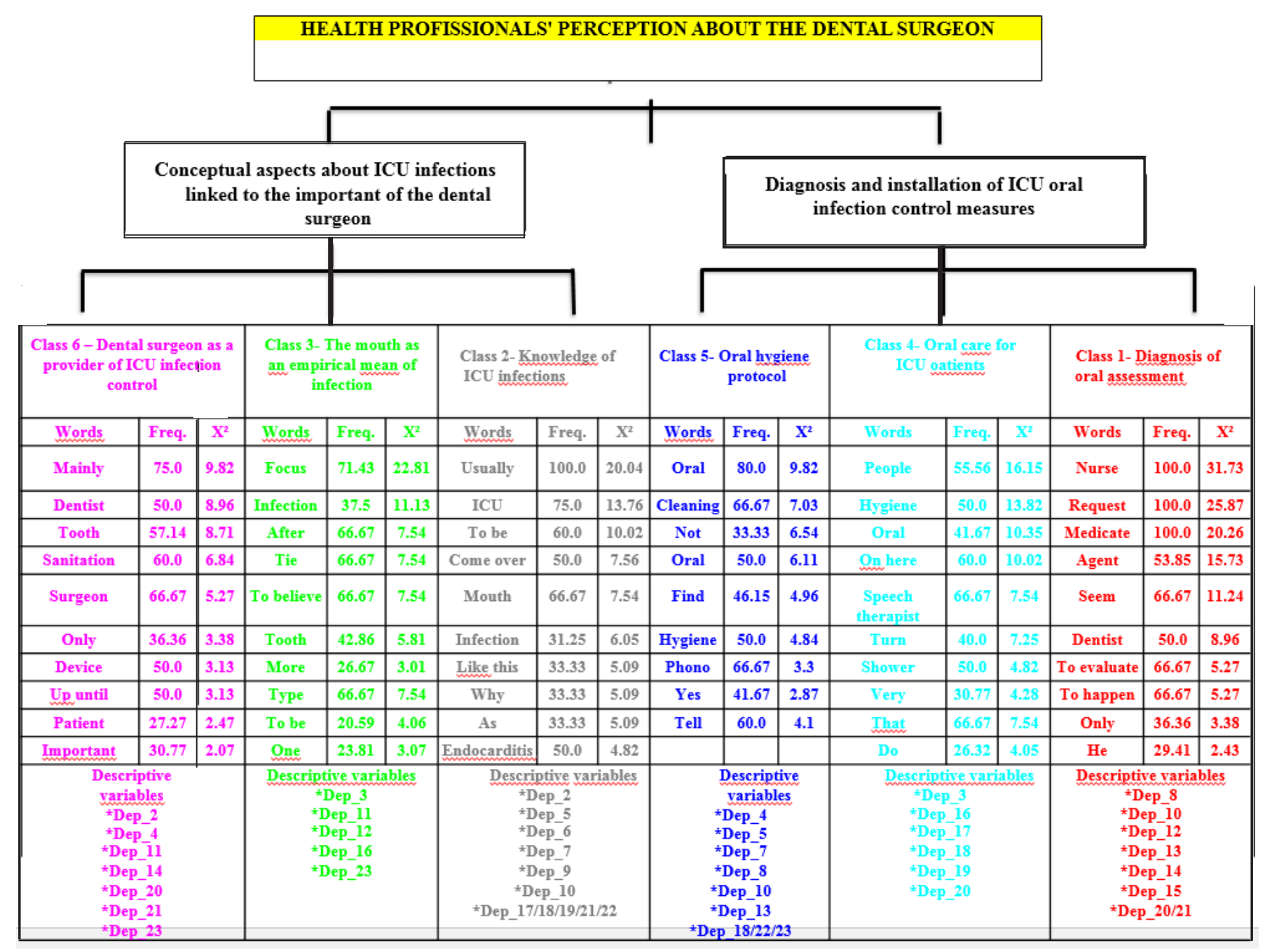

Figure 1. Heath professional's' perception about the dental surgeon.

measures, divided into three classes: class 4- Oral care for ICU patients. Class 5- Protocols of oral hygiene. Class 1Diagnosis of oral evaluation. Axis 2- Concepts about ICU infections linked to the importance of DS, was di-vided into three classes: Class 2- Knowledge about ICU infections. Class 3- The mouth as an empirical means of infection. Class 6 - Dental surgeon as an ICU infection prevention provider.

\section{DISCUSSION}

The corpus analyzed as a whole contained elements that addressed the perception of health professionals related to the importance of the dentist in the ICU. Initially, the corpus as a whole was divided into two segments, leaving two sub-groups, one with a set of three classes $(6,3,2)$ and another subgroup with three classes $(5,4,3)$.

Axis 1- Diagnosis and installation control measures of oral infections in ICU

\section{Class 4 - Oral Care for ICU patients}

With 7 ECUs which correspond to $13.73 \%$ of the total corpus and is directly related to class 5 . The words (people, hygiene, oral, here) all with significant association $(<0.0001)$ were selected by frequency and higher $\left(\chi^{2}\right)$ values in this class.

The perception of ICU health professionals about the means of oral hygiene for hospitalized patients is 
directly linked to the guidance of professionals on patient care, as follows:

"... It will help a lot in the oral hygiene of patients, guidance on how to do it, how often to do it and periodontal diseases..." (Deponent_17).

"... I think it's a lot because of oral hygiene sometimes because a quick cleaning is done during the shower..." Deponent_16).

"... we even did a training ... here at the hospital teaching us how to do oral hygiene ..." (Deponent_18).

The complexity of activities aimed at promoting oral health for ICU patients is based on the great unpreparedness of professionals, when they find it difficult to perform such procedures, especially by the professionals who are responsible for them [12].

Most ICU hospitalized patients need trained and well-oriented professional support for an adequate restoration of oral quality. By the foregoing [13], it can be observed in the literature that ICU patients have poor oral hygiene, which may be due to the lack of supervision. Inter professional dentistry and nursing, thus one of the functions of the ICU dentist would be to guide and supervise nursing technicians to perform proper oral hygiene [4].

In this context, oral hygiene interventions should be routine in ICUs, as they contribute significantly to the balance of oral microbiota, enabling a healthy oral environment and, consequently, the reduction of infectious diseases. Therefore, it is extremely important to invest in professional training so that there are no errors due to lack of knowledge.

\section{Class 5 - Oral Hygiene Protocols}

With 12 ECUs that correspond to $23.53 \%$ of the total corpus and is directly related to class 4 . The words (oral, clean, non-oral) all with significant association $(<0.0001)$ were selected by frequency and higher $\left(\chi^{2}\right)$ values. in this class.

The need for dental treatment in ICU patients requires an assessment of the oral condition and follow-up by a DS that is capable of developing clinical, technical and scientific research conducts mainly in the evaluation of oral health as a whole and its relationship with the condition. systemic treatment [14].
In this sense, it can be observed from the reports that $0.12 \% \mathrm{CHX}$ (chlorhexidine) is used as a measure of oral health promotion and as routine practices em-ployed in the ICUs of the participating hospitals, facts illustrated in the following statements:

"... it really does with chlorhexidine ... that's when the family brings it because some-times it has the question of plans they cover others they don't cover ..." (Deponent_4). "... intubated patients who make cleaning a little difficult would be interesting ... to give guidance to nursing technicians in this area of cleaning ..." (Depoente_5).

"... If he is consciously oriented, he asks him not to swallow and rinse his mouth like any rinse..." (Deponent_10).

"... because the agent does not understand much only cleans with chlorhexidine ..." (Deponent_13).

The motor ability and understanding of patients will guide oral hygiene guide-lines, because in most cases, physical or mental causes can prevent satisfactory oral hygiene, making the proper training of someone to perform this function extremely important [15]. However, it is of great importance to differentiate between patients according to their level of consciousness, as their clinical condition will deter-mine the best protocol [16].

There is still a great lack of suggestions about dental care protocols for ICU patients, although it is already well established the importance of the DS in the interdisciplinary team of these units. In most Brazilian hospital units there is no oral infection control protocol and its implementation can help to reduce the mortality of patients admitted to these ICUs, it is noteworthy that the cooperation between DS and health team will offer benefit to the patient within these units [7].

Although antibiotic use is very common within ICUs, the method of choice for oral cavity cleaning is the application of topical antiseptics, as they do not present the risk of developing microbial resistance [17]. Thus, $\mathrm{CHX}$ (chlorhexidine) has been shown to be the antiseptic of choice in ICU oral hygiene protocols because it is a potent antimicrobial, with broad spectrum of action, high substantivity, because it has a non-specific mechanism of action and also because have systemic toxicity, and substantially decrease the colonization of the oral cavity.

The study corroborates the findings in the literature and shows how critical it is for teams to be trained and able to correctly perform cleaning protocols, and to 
effectively perform the hygiene of teeth, gums, tongue and cheek with appropriate materials, thus preventing, the installation and development of infections promoting the health of patients.

\section{Class 1 - Diagnosis of oral assessment}

With 9 ECUs which corresponds to $17.65 \%$ of the total corpus. The words (nurse, solicit, medicate, agent) all with significant association $(<0.0001)$ were selected by frequency and higher $\left(\chi^{2}\right)$ values in this class.

In the lack of knowledge of health professionals about pathologies and methods of dental prevention, there are deprivations in the training of dentists to work in ICU patients, where preventive therapy is essential as a method of reducing opportunistic diseases [18].

In this context, this class showed who makes the diagnosis and evaluation of oral infections in ICU patients, and can be observed in the following statements:

"... If we suspect we ask for an opinion from a dental surgeon... a dental surgeon on the scale doesn't have... the doctor evaluates it" (Deponent_08).

"... an agent tries to treat before calling the doctor ... the doc-tor on duty until he requests the presence of a dentist." (De-ponent_10).

"... we observe communicates the nurse he communicates the doctor and requests a dentist." (Deponent_14).

"... nurse and she communicates to the doctor and he asks an opinion of a dentist, but rarely this happens only remember one that was to remove a device." (Deponent_20).

"... He makes the request by the opinion he asks and he comes to assist, but he is not part of the team" (Deponent_21).

The integration of the DS with the hospital staff helps to prevent infections, reducing the length of stay and the use of medications [19]. The objective of the DS is to perform a proper clinical examination in the hospitalized patient, seeking to assess if there is any presence of oral alteration and remove possible infectious foci by performing scraping, surgery, dressings, restorations and drug interventions, bleeding prevention, treatment oral lesions and palliative treatments, thus allowing the medical treatment not to be interrupted and the patient to recover quickly [20].

The performance of the DS covers both preventive, therapeutic and rehabilitative aspects, where prevention actions mainly involve the implementation of oral hygiene protocols, establishment of daily visits in addition to the intraoral physical examination. In addition, the diagnosis of oral pathologies can be performed by the $C D$, as it is a professional more prepared for this function, assisting in therapy, as several clinical situations require adaptations and treatment of oral complications, which are extremely necessary procedures to promote comfort. and better quality of life of patients [21].

However, this study demonstrates that the addition of DS to the multidisciplinary team is critical to ensure more holistic and comprehensive patient care, contributing to accurate diagnosis, proper prevention, better prognosis and rapid recovery.

\section{Class 2 - Knowledge of ICU infections}

With 7 ECUs which corresponds to $13.73 \%$ of the total corpus. The words (generally, uti, to be, to come) all with significant association $(<0.0001)$ were select-ed by frequency and higher $\left(\chi^{2}\right)$ values in this class.

The increase in the possibility of acquiring infectious diseases that may com-promise the health of ICU patients is due to the impossibility of self-care, so class 2 discusses the knowledge of ICU professionals about infections acquired due to poor oral hygiene, such as We can see in the testimonials below:

"... When the patient will swallow... and if his mouth is not clean, he will accumulate dirt and acquire some infection such as pneumonia... endocarditis..." (Deponent_21).

"... I think in the case of respiratory infection ... we observe and report to the doc-tor." (Deponent_22).

"... pericarditis pneumonia ... a case has already happened ... it was an oral infec-tion that was an abscess." (Deponent_2).

"... several lung infections ..." (Deponent_6).

"... at first respiratory infections ... the risk of an infection can cause sepsis endocar-ditis ..." (Deponent_11).

"... respiratory and heart diseases such as endocarditis ..." (Deponent_18). 
The ICU is the sector that has the highest rate of nosocomial infections, so it is of great value that the professionals in the staff have knowledge of nosocomial infections, methods of transmission, prevention and dissemination of microorgan-isms. The systemic diseases that are more present in hospitals and related to oral health include nosocomial pneumonia and bacterial endocarditis, emphasizing that they cannot be presented in isolation, but may be influenced by other health conditions [22].

Poor oral hygiene is a risk factor for endocarditis infection. Even simple tooth brushing can cause bacteremia, which can lead to bacterial endocarditis [23]. Starting from the author, he states that when there is periodontal disease, the bacterium falls into the bloodstream and may settle in the heart and heart valves, thus highlighting the need for conducts that focus on preventing the onset of infection [24].

In the first 48 hours of the patient in the ICU, they have contact with multire-sistant respiratory pathogens, which have affinity with the oral biofilm microorgan-isms, which in turn becomes the true reservoir of microorganisms. With the in-creased volume of this biofilm, its complexity, and the presence of other oral compli-cations such as traumatic, infectious lesions, xerostomia, dental cavities, may in-crease the possibility of developing serious respiratory diseases, offering life-threatening, as is the case of nosocomial pneumonia [25].

There is a relationship between poor oral hygiene and increased risk of bac-terial endocarditis, where studies have shown that patients with stone and biofilm have a higher risk of bacteremia to be acquired in hospital settings, especially in ICU, requiring conducts. directly related to biofilm removal and elimination of factors related to the gingival process [23].

The study corroborates the authors' statements, when they report that poor oral hygiene may be responsible for the emergence of nosocomial infections such as bacterial endocarditis and nosocomial pneumonia.

\section{Class 3 - The mouth as an empirical means of infection}

With 7 ECUs which corresponds to $13.73 \%$ of the total corpus. The words (fo-cus, infection, then believe), all with significant association $(<0.0001)$, were selected by frequency and higher $\left(\chi^{2}\right)$ values in this class.
In the oral cavity is found almost half of the microbiota present throughout the body, represented by various species of bacteria fungi and viruses claim that the mouth. Among all parts of the human body, it has the largest variety of microorgan-isms, due to their physiological and anatomical characteristics, which may vary with the amount of oxygen, temperature exposure to immune factors and nutrient availa-bility [26].

Thus, this class reports that the mouth is a focus of infection caused by poor oral hygiene, which can be observed in the following reports::

"... sometimes there are infections that start with problems in some teeth that could be avoided ..." (Deponent_16).

"... he extracted some teeth that were foci of infection ..." (Deponent_23).

"So surely that is the focus of infection... it helps to contribute or perpetuate an in-fectious process or a dental abscess..." (Deponent_3)

Dental plaque or biofilm has a high rate in ICU patients. The authors verified that after 10 days of intubation there was a predominance of aerobic pathogens and that the colonization of these microorganisms present in the plaque/biofilm could serve for the evolution of nosocomial infections in ICU patients [27].

ICU patients have poor oral hygiene and a significant amount of biofilm, so the amount and complexity of the biofilm may increase with length of stay. There-fore, it is essential to sanitize the mouth of these patients to ensure that there is no spread of bacteria and fungi that harm the well-being of the patient, their oral and systemic health causing other infections and diseases [28].

In accordance with the above, the mouth may become a deposit of microor-ganism, being of great importance in the systemic infectious disease processes in hospitalized patients, and that these microorganisms present in the mouth deterio-rate the conditions of periodontal tissues, recognizing that the installation and pro-liferation of these microorganisms are linked to the environment, low oxide-reduction potential, and favor the spread of these infectious agents distant from the mouth as central nervous and cardiovascular system [29].

In this scenario, the inclusion of a DS in the ICU interdisciplinary team be-comes indispensable, given that this integration is beneficial for the effective devel-opment 
of routine activities, such as the implementation of oral hygiene in the daily routine, knowing that this practice plays an important role in the prevention of com-plications and nosocomial infections, thus ensuring the maintenance of adequate oral conditions.

\section{Class 6 - Dental Surgeon as ICU Infection Prevention Provider}

With 09 ECUs which corresponds to $17.65 \%$ of the total corpus. The words (mainly dentist, tooth, hygiene) all with significant association $(<0.0001)$ were se-lected by frequency and higher $\left(\chi^{2}\right)$ values in this class.

The dental surgeon plays a very important role in the context of the ICU team, as it acts in the implementation of the concept of integral health, supporting the team when it comes to care, dynamization and optimization of interdisciplinary work, acting in the decision making process, based on a solid understanding of new ther-apies and physiological and psychological conditions of patients [30].

In this context, this class discusses the importance of implanting the DS with-in the ICU and its role in infection control and prevention, facts illustrated in the fol-lowing statements:

"... we don't work with a dental surgeon ... I think the main thing is to decrease the numbers of mechanical ventilationassociated pneumonia infection, if I had the dentist would surely decrease. (Deponent_02)

"... the importance is that having a dental surgeon will have a closer monitoring especially these intubated patients ... see the issue of hygiene ... I think this is very important". (Depo-nent_04)

"So, there is no follow-up, only if you are a traumatized patient and you call a bucomaxyl ..." (Deponent_11).

"... I think because there are many patients who have only that shard of tooth and are feeling a lot of pain, even to clean it is difficult because we do not know the correct way to wash their mouth and there are people even aware that is bothered. "(Deponent_14).

"... Because it's actually a multiprofessional team and there has to be every area. "(Deponent_21).

The practice on dentistry in the ICU is recent when it comes to the level of Brazil. The DS as an integral part of these teams, has been discussed for some years in the clinical, scientific and political, through a bill number 2776/2008, which makes mandatory the presence of dental surgeons in Intensive Care Units and oth-ers. public and private institutions that keep patients under hospitalization, in order to treat the oral health of patients and that they should receive the care of this pro-fessional [6].

The interdisciplinary view of the staff involved in ICUs requires clinical con-duct that requires the constant presence of the DS for resolution or guidance on possible problems that may arise, because in some clinical activities other team members are not qualified to perform, thus requiring guidance and training in the dental context with appropriate techniques for oral health promotion [31].

The changes in the expectation and quality of life of the Brazilian cause the DS to find daily patients with different types of oral and systemic diseases, which may or may not be related to each other. Therefore, it is necessary that the DS has greater knowledge about the general health of the patient and that hospitals adopt multidisciplinary teams integrating their clinical staff to achieve the comprehensive health of hospitalized patients, highlighting that these patients need rigorous care due to a situation. deficient clinical condition, which makes them more susceptible to oral and/or systemic infections, worsening their general health [7].

Although the legislation defines the need for the DS in ICU teams, it is still not met by many hospitals. This study demonstrated the importance of the ICU's DS and that the performance of the dental professional is essential for the establishment of prevention and care in the oral health of the patient, as well as preparing the team to perform the procedures, use of equipment and materials appropriate to care to these patients.

\section{CONCLUSION}

It is evident the importance of the presence of DS in the multidisciplinary team of ICUs to ensure a comprehensive and comprehensive treatment of the patient, promoting the possibility of an accurate diagnosis, adequate prevention, prognosis, improving the quality of life of these individuals. The research suggests the need for the effective participation of the DS as a member of the ICU team, promoting appropriate training for 
multidisciplinary team professionals and can positively induce a more consistent practice of oral care, also suggesting the implementation of institutional protocols directed to patients in these units.

\section{Collaborators}

BL SILVEIRA worked on the theoretical conception, analysis and discussion of the data. DLP MENESES worked on data analysis and discussion. ESL VERAS worked on data analysis and discussion. LKB MOURA worked on theoretical design, data collection, analysis and discussion of the data, and final writing of the manuscript. JP MELO NETO worked on data analysis and discussion. MSAE MELO worked on the final writing of the manuscript.

\section{REFERENCES}

1. Whelton H, Crowley E, O'Mullane D. Oral health of irish adults 2000-2002. Dublin: Department of Health and Children; 2007.

2. World Health Organization. Oral health surveys: basic methods. 4 ed. Geneva: World Health Organization; 1997.

3. Nelson JE. et al. Models for structuring a clinical initiative to enhance palliative care in the intensive care unit: a report from the IPAL-ICU Project (improving palliative care in the ICU). Crit CareMed. 2010;38(9):1765-1772. https://doi.org/10.1097/ CCM.0b013e3181e8ad23

4. Aranega AM. et al. Qual a importância da Odontologia Hospitalar? Revista Brasileira de Odontologia. 2012; 69(1):90. http://dx.doi.org/10.18363/rbo.v69n1.p.90

5. Silveira IR da, Maia FOM, Gnatta JR, Lacerda Rúbia AL. Higiene bucal: prática relevante na prevenção de pneumonia hospitalar em pacientes em estado crítico. Acta Paulista de Enfermagem. 2010; 23 (5), 697-700. https://doi.org/10.1590/ S0103-21002010000500018.

6. Santos PSS, Mello WR, Wakim RCS, Paschoal MAG. Uso de solução bucal com sistema enzimático em pacientes totalmente dependentes de cuidados em unidade de terapia intensiva. Rev Bras Ter Intensiva. 2008;20(2):154-159. https:// doi.org/10.1590/S0103-507X2008000200007.

7. MATOS, F.Z. et al. Conhecimento do Médico Hospitalar Referente à Higiene e as Manifestações Bucais de Pacientes Internados. Pesq Bras Odontoped Clin Integr. 2013; 13(3):239-43. https://doi.org/10.4034/PBOCI.2013.133.03

8. Brasil. Câmara dos Deputados - Congresso Nacional. Projeto de Lei n. ${ }^{\circ}$ 2.776-A 13 de fevereiro de 2008. Estabelece a obrigatoriedade da presença de profssionais de odontologia em UTI [Internet]. Brasília, DF;2012. [ 2018 citado Mai 10]. Disponível em: <http://http://www.camara.gov.br>.

9. Gomes SF, Esteves MCL. Atuação do cirurgião-dentista na UTI: um novo paradigma. Revista brasileira de odontologia. 2012, 69(1):67-70. https://dx.doi.org/10.18363/rbo.v69n1.p.67
10. Londe LP, Ferreira JA, Novaes LACF, Barbosa RS, Miranda AF. Pneunomia Nosocominal e sua relação com a saúde bucal. Revista Ciências e Odontologia. 2017, 1(1), 24-28. Disponível em: http://revistas.icesp.br/index.php/RCO/article/view/141

11. Amaral COFD, et al. Importância do cirurgião-dentista em Unidade de Terapia Intensiva: avaliação multidisciplinar. Rev. Assoc. Paul. Cir. Dent. 2013, 67(2),107-111. Disponível em: http://revodonto.bvsalud.org/pdf/apcd/v67n2/a04v67n2.pdf

12. Camargo BV, Justo AM. IRAMUTEQ: um software gratuito para análisede dados textuais. Temas psicol. [online]. 2013; 21(2), 513-518. http://dx.doi.org/10.9788/TP2013.2-16

13. Minayo MCS. Amostragem e saturação em pesquisa qualitativa: consensos e controvérsias. Revista Pesquisa Qualitativa [Internet]. 2017 [citado 2018 Jun 2]; 5 (7): 1-12. Disponível em: https://editora.sepq.org.br/index.php/rpq/article/view/82/59 [ Links ].

14. Rodrigues SS, Caminha MFC, Ferraz MGG, Arruda MA, Kozminshy VMR, Guerra CARM. Knowledge, Attitude and Practice of the Nursing Team Re-garding Oral Health Care in Intensive Care Units in a Reference Hospital of Recife, Brazil. Braz Res Ped Dent Int Clin, 2016; 16(1): 129-139. http://dx. doi.org/10.4034/PBOCI.2016.161.14

15. Lima DC, Saliba NA, Garbin AJl, Fernandes LA, Garbin CAS. A importância da saúde bucal na ótica de pacientes hospitalizados. Ciência \& Saúde Coletiva. 2011,16(Supl. 1):1173-1180. https://doi.org/10.1590/S1413-81232011000 700049

16. Rabelo GD, Queiroz CI, Santos PSS. Atendimento odontológico ao paciente em unidade de terapia intensiva. Arq Med Hosp Fac Cienc Med Santa Casa São Paulo. 2010;55(2):67-70. Disponível em: http://189.125.155.35/index.php/AMSCSP/ article/view/337/362

17. Araújo RJGD, Oliveira LCGD, Hanna LMO, Corrêa AM, Carvalho LHV, Alvares NCF. Análise de percepções e ações de cuidados bucais realizados por equipes de enfermagem em unidades de tratamento intensivo. Rev Bras Ter Intensiva. 2009; 21(1): 38-44. https://doi.org/10.1590/S0103-507X20 09000100006.

18. Assis A. Atendimento odontológico nas utis. Rev Bras Odontol. 2012; 69(1): 72-75. . Disponível em: http://revodonto.bvsalud. org/pdf/rbo/v69n1/a16v69n1.pdf

19. Beraldo CC, De Andrade D. Higiene bucal com clorexidina na prevenção de pneumonia associada à ventilação mecânica. J Bras Pneumol. 2008;34(9):707-714. https://doi.org/10.1590/ S1806-37132008000900012.

20. Pasetti LA, Carneiro Leão MT, Araki LT, Albuquerque AMN, Ramos TMB, Santos SF et al. Odontologia Hospitalar A Importância do Cirurgião Dentista na Unidade deTerapia Intensiva. Rev. Odontologia (ATO). 2013;13(4):211-226.

21. Santana A, Xavier DC, Santos KL,Menezes MV, Piva RM, Werneck Rl. Atendimento odontológico em UTI (unidade de terapia intensiva). Disponível em: http://www.herrero.com.br/ files/revista/file9628c9b5725d35466e68b017d0acc107.pdf

22. Lopes DR. Odontologia hospitalar - uma realidade. Disponível em: http://jornaldehoje.com.br. Acesso em: 2 de maio de 2018. 
23. Curi MM, Beethoven EC, Cristina Z, Daniel HK, Rosenvaldo M, Jessyca MA, Camila LC. Lesão traumática severa em paciente internado em UTI. SALUSVITA. 2017,36(3)725-735. Disponível em: https://secure.usc.br/static/biblioteca/salusvita/ salusvita_v36_n3_2017_art_07.pdf

24. Kahn S, Mangialardo AS, Garcia CH, Namen FM, Júnior JG, Machado WAS. Controle de infecção oral em pacientes internados: uma abordagem direcionada aos médicos intensivistas e cardiologistas. Ciênc Saúde Coletiva [online], 2010;15 (supl.1):1819-1826. https://doi.org/10.1590/S1413-8 1232010000700094.

25. Lockhart PB, Brennan MT, Thornhill M, Michalowicz BS, Noll J, Bahrani-Mougeot FK, Sasser HC. Poor oral hygiene as a risk factor for infective endo-carditis-related bacteremia. J Am Dent Assoc. 2009;140(10):1238-1244. https://doi. org/10.14219/ jada.archive.2009.0046

26. Türk G, Kocaçal Güler E, Eşer I, Khorshid L. Oral care practices of intensive care nurses: a descriptive study. Int J Nurs Pract. 2012, 18(4):347-353. https://doi.org/10.1111/j.1440-172X.2012. 02045.x

27. Makabe MLF. Higienização bucal com digluconato de clorexidina e extrato etanólico de própolis em pacientes de Unidade de Terapia Intensiva (UTI) de um Hospital Público na cidade de São Paulo. São Paulo. 2015. Tese de doutorado. Secretaria de Estado da Saúde de São Paulo.

28. Schlesener VRF, Rosa RU, Raupp SMM. O cuidado com a saúde bucal de pacientes em UTI. Cinergis. 2012; 13(1): 73-77. https://doi.org/10.17058/cinergis.v13i1.3164.

29. Morais TMN, Silva A, Santos PSS. Odontologia na Unidade de Terapia Intensiva. In: Santos PSS; Soares Junior LAV. Medicina Bucal: A Prática na Odontologia Hospitalar. São Paulo: Santos. p.336, 2012.

30. Gomes-Filho IS, Oliveira TF, Cruz SS, Passos-Soares JS, Trindade SC, Oliveira MT, et al. Influence of periodontitis in the development of nosocomial pneumonia: a case control study. J Periodontol. 2014;85(5): e82-90. https://doi.org/10.1902/ jop.2013.130369

31. Zuanazzi D, Souto R, Mattos MB, Zuanazzi MR, Tura BR, San-sone C, Co-lombo AP Prevalence of potential bacterial respiratory pathogens in the oral cavity of hospitalised individuals. Arch Oral Biol. 2010;55(1):21-28. https://doi.org/10. 1016/j.archoralbio.2009.10.005

Received on: 11/4/2019 Approved on: 26/7/2019 